\title{
Osmotic and morphological effects on red blood cell membrane: action of an aqueous extract of Lantana camara
}

\author{
Adalgisa I. Maiworm, ${ }^{*, 1,2}$ Giuseppe A. Presta, ${ }^{1,2,3}$ Sebastião D. Santos-Filho, ${ }^{1,2}$ Severo de \\ Paoli, ${ }^{1,2}$ Tânia S. Giani, ${ }^{1,2}$ Adenilson S. Fonseca, ${ }^{2}$ Mario Bernardo-Filho, ${ }^{*, 1,2}$ \\ ${ }^{1}$ Universidade Federal do Rio Grande do Norte, Programa de Pós-Graduação em Ciências da Saúde, Avenida \\ General Gustavo de Farias s/n, 59010-180 Natal-RN, Brazil, \\ ${ }^{2}$ Universidade do Estado do Rio de Janeiro, Instituto de Biologia Roberto Alcântara Gomes, Departamento de \\ Biofisica e Biometria, Avenida 28 de Setembro 87, 20551-030 Rio de Janeiro-RJ, Brazil, \\ ${ }^{3}$ Instituto Nacional do Câncer, Coordenadoria de Pesquisa, Praça Cruz Vermelha 23, 20230-130 \\ Rio de Janeiro-RJ, Brazil
}

\begin{abstract}
RESUMO: "Efeitos osmótico e morfológico na membrana de hemácias: ação de um extrato aquoso de Lantana camara". As infusões de folhas de Lantana camara (cambara-de-espinho) são usadas popularmente em alguns países para tratar doenças gastrointestinais. O experimento de fragilidade osmótica e a análise morfométrica têm sido usados para verificar a interação de drogas com a membrana de hemácias. O objetivo deste trabalho foi avaliar os efeitos de um extrato aquoso de Lantana camara na fragilidade osmótica e na morfologia de hemácias. Amostras de sangue foram tratadas com extrato de Lantana camara $(10 \mathrm{mg} / \mathrm{mL})$, o ensaio de fragilidade osmótica e a análise morfológica foram realizadas. Na presença do extrato, os dados obtidos indicaram (i) um aumento significativo $(p<0,05)$ da hemólise e (ii) modificações na morfologia das hemácias. Estes efeitos da Lantana camara poderiam estar associados com algumas propriedades farmacológicas de compostos químicos do extrato estudado.
\end{abstract}

Unitermos: Lantana camara, Verbenaceae, morfologia, fragilidade osmótica, hemácias.

\begin{abstract}
The Lantana camara ("cambara de espinho") leaves infusions are used popularly in some countries to treat gastrointestinal diseases. Osmotic fragility assay and morphometric analysis have been used to verify the interaction of drugs with the membrane of red blood cells (RBC). The aim of this work was to evaluate the effects of an aqueous extract of Lantana camara on the osmotic fragility and on the morphology of RBC. Blood samples were treated with extract of Lantana camara $(10 \mathrm{mg} / \mathrm{mL})$, osmotic fragility assay and morphological analysis were carried out. In the presence of the extract, the data obtained indicated (i) a significant $(p<0.05)$ increase of hemolysis and (ii) modifications on the morphology of RBC. These effects of the Lantana camara may be associated with some pharmacological properties of the chemical compounds of this studied extract.
\end{abstract}

Keywords: Lantana camara, Verbenaceae, morphology, red blood cells, osmotic fragility.

\section{INTRODUCTION}

The Lantana camara (cambara-de-espinho) leaves infusions are used popularly in some countries to treat gastrointestinal diseases, as emenagogue, diuretic, expectorant and antirheumatic. (Hernandes et al., 2003; Sagar et al., 2005; Agra et al., 2007). Lantana camara plant has been reported to possess a number of pharmacological properties as antipyretic, antimicrobial, antimutagenic, antithrombin, anti-inflammatory, antitumor, inhibitors of the enzyme acetylcholinesterase and antinoceptive (Ahmed et al.,1972; Sashi et al., 1994, Ghisalberti, 2000; Uzcategui et al., 2004; Zheng et al., 2006; Barbosa-Filho et al., 2006; Misra et al., 2007). The importance of this plant has promoted their inclusion in
Brazilian Pharmacopoeia (Brandão et al., 2006)

The chemical compounds present in Lantana camara extracts include mono and sesquiterpenes, flavonoids, iridoid glycosides, furanonaphoquinones, sthsteroids and phenyl ethanoid glicosides, triterpene and diterpenes.(Ghisalbert, 2000).

The volume of the red blood cells (RBC) seems to be regulated by a direct action of the sodiumpotassium pump that controls the solute concentration inside the cell, thereby regulating the osmotic forces that can make a cell swell or shrink (Alberts et al., 2002). The resistance of $\mathrm{RBC}$ to hemolysis characterizes what is called the osmotic fragility (OF) of the cell membrane. The osmotic fragility is classically used as an in vitro assay to evaluate the effects of natural 
and synthetic drugs on membrane (Didelon et al., 2000). The "fragility curve" reflects the structural and geometrical changes in RBC. Hemolysis results from a structural perturbation of the RBC and cytoskeleton caused by high partition in the membrane (Cruz Silva et al., 2000; Didelon et al., 2000).

$\mathrm{RBC}$ have been proposed as a prototypical cellular system regarding drug mediated plasma membrane effects (Li et al., 1999). Different techniques have demonstrated that therapeutic drugs can modify the structure and morphology of these cells (Nwafor and Coakley, 1986; Scheiman and Elta, 1990; Li et al., 1999; Shacter and Weitzman, 2002; Suwalsky et al., 2003; Hubner et al., 2005; Santos et al., 2005; Zhang et al., 2005).

The aim of this study was to investigate the effects of an aqueous extract of the Lantana camara on the osmotic fragility and on the morphology of red blood cells using in vitro studies.

\section{MATERIAL AND METHODS}

\section{Animals}

The animals were maintained under environmental conditions $\left(25 \pm 2{ }^{\circ} \mathrm{C}, 12 \mathrm{~h}\right.$ of light/ dark cycle), water ad libitum and normal diet. Blood was withdrawn by cardiac puncture with a heparinized syringe from adult male Wistar rats $(\mathrm{n}=6,3-4$ months, $245 \pm 35 \mathrm{~g}$ ). The experimental procedures have followed the Ethical Guidelines of the Instituto de Biologia Roberto Alcantara Gomes, Universidade do Estado do Rio de Janeiro with the protocol number CEA/127/2006.

\section{Identification and preparation of the Lantana camara extract}

The leaves were collected in the forest of the city of Petrópolis, State of Rio de Janeiro, Brazil. The material collected was identified by the Biologist Ricardo Carneiro da Cunha Reis, Botanic Herbarium RB of the Jardim Botânico, State of Rio de Janeiro, Brazil, where a voucher specimen (4070081) was kept. The extract of Lantana camara was prepared with leaves triturated (150 mg, dried in ambient air) added in $15 \mathrm{~mL}$ of boiling $0.9 \% \mathrm{NaCl}$ during 10 minutes. The preparation was filtered through paper (quality filter paper) and considered as $10 \mathrm{mg} / \mathrm{mL}$. As reproducibility control of the extract was used the value of the absorbance of a aliquot of extract at $480 \mathrm{~nm}(0.17 \pm 0.03)$ determined in a spectrophotometer (ANALYSER 800M ANALYSER Comércio Indústria LTDA, São Paulo).

\section{The experimental procedure}

The osmotic fragility evaluations of the RBC were performed with whole blood samples incubated with Lantana camara extract $(10 \mathrm{mg} / \mathrm{mL})$ or with sodium chloride solution $(0.9 \% \mathrm{NaCl})$ as a control for 60 minutes at room temperature. Samples of these whole blood (control and treated) were centrifuged (Clinical centrifuge, BIO ENG Ind e Com LTDA) and aliquots of RBC are separated. Briefly, RBC samples $(100 \mu \mathrm{L})$ treated with Lantana camara extract or with saline solution (control) were gently mixed with different hypotonic $\mathrm{NaCl}$ (from 0.12 to $0.9 \%$ ) solutions (Dacie and Lewis, 2001). After $60 \mathrm{~min}$, at room temperature, the preparations were centrifuged (1500 rpm, 15 minutes). The supernatants were isolated and the optical density (OD) to each $\mathrm{NaCl}$ concentration was in a spectrophotometer (ANALYSER 800M, Analyser Comércio Indústria LTDA, São Paulo) at $540 \mathrm{~nm}$. The OD of each supernatant was compared with the OD of the $0.12 \% \mathrm{NaCl}$ solution ( $100 \%$ of lysis). The supernatant at $0.9 \% \mathrm{NaCl}$ was considered the blank for the preparation, because it has no hemolysis. In according to fragility curve tendency, three intervals were determinated: interval I between 0.12 and $0.36 \% \mathrm{NaCl}$, interval II between 0.36 and $0.60 \% \mathrm{NaCl}$ and interval III between 0.60 and $0.90 \% \mathrm{NaCl}$ (Cavalcanti et al., 2003). After measuring of osmotic fragility, "fragility curves" were drawn by plotting the percentage of lysis or hemolysis (\% hemolysis) for each tube (relative to $100 \%$ hemolysis tube) and the corresponding concentration of $\mathrm{NaCl}$. The experiments were analyzed with paired t-test to verify potential differences between hypotonic and isotonic phases $(\%$ concentrations of $\mathrm{NaCl})$ versus relative hemolysis ( $\%$ hemolysis $)$.

\section{Morphological evaluation}

Histological preparations were carried out with blood samples in vitro treated with the extract of Lantana camara $(10 \mathrm{mg} / \mathrm{mL})$ during $60 \mathrm{~min}$ at room temperature, or with saline solution as control group. Blood smears were prepared, dried, fixed and staining by May-Grünwald-Giensa method (Junqueira and Carneiro, 2004). After that, the images of the red blood cells were acquired (Optronics, USA) from blood smears to qualitative morphology analysis under optical microscopy (x1000, Olympus, BX model, Japan).

\section{Statistical analysis}

The data of mean of hemolysis percentage in each interval in the fragility curve were presented as means \pm standard deviation. Paired t-test was used to compare the intervals I, II and III between treated and control groups. A significance level at $p<0.05$ was adopted. InStat Graphpad software was used to perform statistical analysis (GraphPad InStat version 3.01 for Windows 95/NT, GraphPad Software, San Diego, USA). 


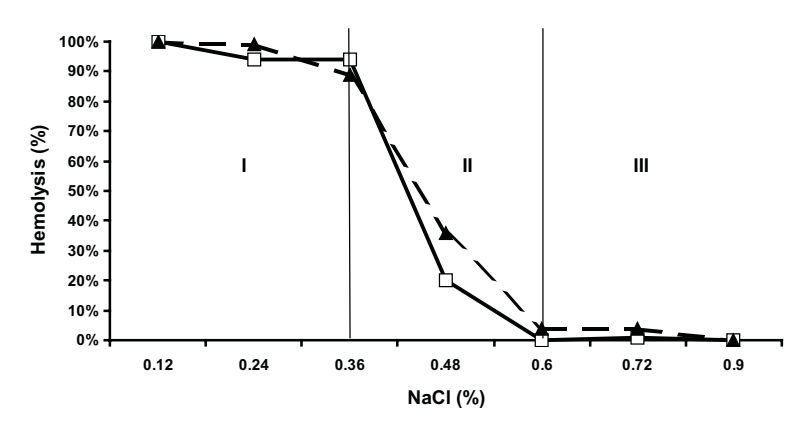

Figure 1. Osmotic fragility of blood samples treated or not treated with extract of Lantana camara. Blood samples were incubated with Lantana camara extract or with sodium chloride solution $(0.9 \% \mathrm{NaCl})$, as control. The hemolysis percentage was calculated and "fragility curves" were drawn plotting the percentage of hemolysis (\% hemolysis) for each $\mathrm{NaCl}$ concentration (relative to $100 \%$ hemolysis tube). ( $\square$ ) Control, (A) Treated with Lantana camara extract.

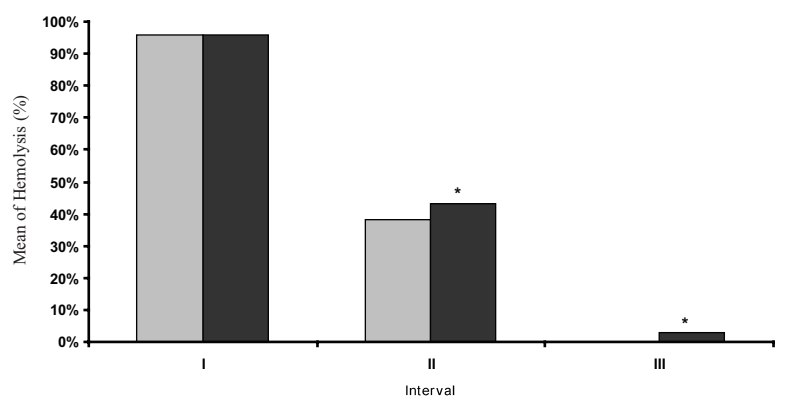

Figure 2. Means of hemolysis of the blood samples treated or not treated with Lantana camara extract. Three intervals were determined in fragility curves: interval I (from 0.12 to $0.24 \%$ $\mathrm{NaCl}$ ), interval II (from 0.24 to $0.48 \% \mathrm{NaCl}$ ), and interval III (from 0.48 to $0.9 \% \mathrm{NaCl}$ ) in according with the curve tendency. The means and standard deviations of each interval were determined and the statistical analysis was performed. ( $\square$ ) Control, (匹) Treated with Lantana camara extract. $(*) \mathrm{p}<0.05$.

\section{RESULTS}

Figure 1 shows the osmotic fragility curves obtained after treatment with an aqueous extract of Lantana camara of RBC samples from Wistar rats. The results indicate that the extract used alters the profile of osmotic fragility curves when compared with the control group. The Figure 2 presents the mean of the hemolysis percentage after analysis of the three $\mathrm{NaCl}$ concentrations intervals obtained from osmotic curve of the figure 1. These data confirm the results presented in Figure 1. The analysis of the results showed a significant statistical increase $(p<0.05)$ on osmotic fragility of RBC incubated with Lantana camara extract in the interval II $(0.36$ to $0.60 \% \mathrm{NaCl})$ and in the interval III $(0.60$ to $0.90 \% \mathrm{NaCl})$ from fragility curve. In the interval $3(0.60$ to $0.90 \% \mathrm{NaCl}$, that is related to the isotonic interval, the osmotic fragility also increased significantly $(p<0.05)$

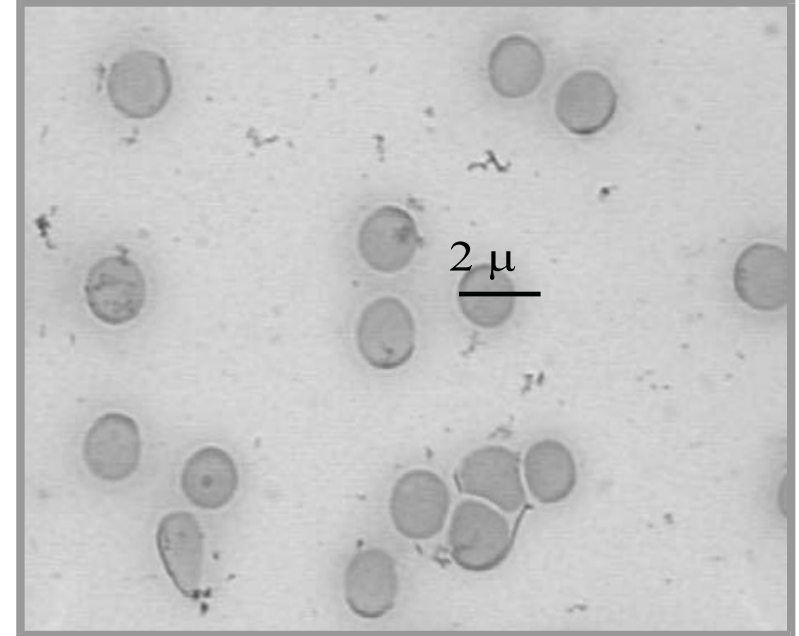

Figure 3. Photomicrography of blood smears from blood samples in vitro treated during 60 minutes with $\mathrm{NaCl} 0.9 \%$ solution (control group). Blood smears were prepared, dried, fixed and stained by May-Grünwald-Giemsa method. The morphology of red blood cells was evaluated under optical microscopy (x1000) after image capture.

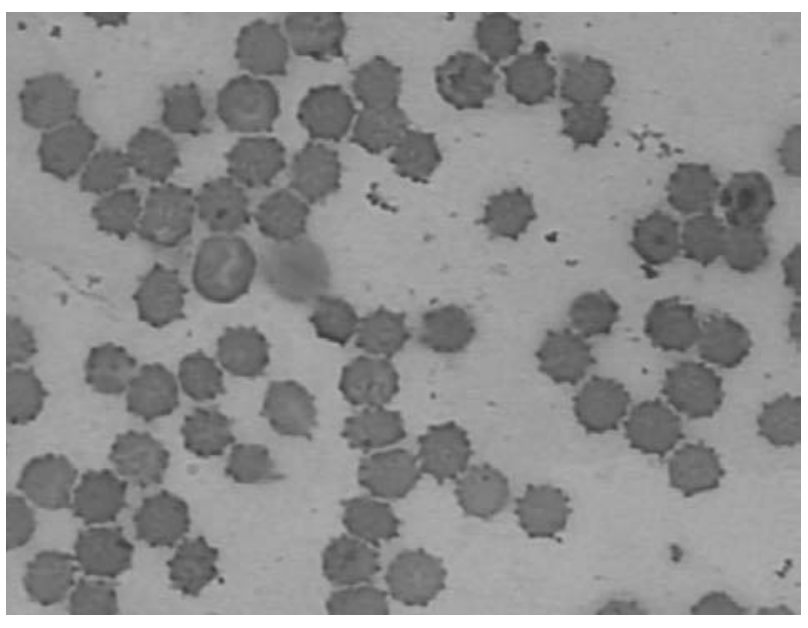

Figure 4. Photomicrography of blood smears from blood samples in vitro treated with Lantana camara extract $(10 \mathrm{mg} / \mathrm{mL})$ during 60 minutes. Blood smears were prepared, dried, fixed and stained by May-Grünwald-Giemsa method. The morphology of red blood cells was evaluated under optical microscopy (x1000) after image capture.

in blood samples treated with Lantana camara extract when compared to control group.

The Figures 3 and 4 represent photomicrographies of blood smears from samples of blood treated with saline (control) and treated with the Lantana camara extract, respectively. The comparison between these figures indicates that the extract is capable to induce alterations on the morphology of the red blood cells.

\section{DISCUSSION}

Authors have described that some drugs 
are capable of inducing alterations on the shape and physiology of the red cells (Ammus and Yunis, 1989; Oliveira et al., 2005). Different techniques have been used to evaluate the effects of the interaction between drugs and plasma membrane (Li et al., 1999, Pompei et al., 2005). The osmotic fragility assay is a classical, rapid, useful and easy technique that has permitted to obtain relevant information about the interactions of natural and synthetic drugs with cellular membrane (Khanna et al., 2002). Morphological analysis is another available method that has permitted to evaluate the effects of natural products on membrane of red blood cells (Oliveira et al., 2002, Oliveira et al., 2003; Presta et al., 2007; Giani et al., 2007).

The data obtained from osmotic fragility assay in this work indicated that Lantana camara extract could alter the membrane integrity at $\mathrm{NaCl}$ concentrations close to physiologic level (Figures 1 and 2). In the same way, the morphological analysis of blood smears suggested alteration on the shape of the red blood cells from whole blood treated with Lantana camara extract (Figures 3 and 4). These alterations on the membrane integrity could be related to components present in the aqueous extract of Lantana camara capable of interacting with membrane components and that could modify the erythrocyte membrane ions transport or the osmotic transport balance.

It was reported that compounds present in Lantana camara alter the function of protein C (Herbert et al.,1991). Other data suggested that an antifilarial (Misra et al., 2007) and antitumor (Shashi et al., 1994) effects to this natural product. Moreover, serveral phrmacological properties have been associated with the studied extract. Taken together, these findings could indicate an action of the chemical compounds of the Lantana camara on membrane structure and they could be in agreement with the results obtained in this work.

In conclusion, the aqueous extract of Lantana camara used could affect the membrane integrity decreasing the osmotic resistance and altering the shape of red blood cells. These findings could be related with some properties of the chemical compounds of this studied extract.

\section{ACKNOWLEDGMENTS}

This research was supported by Fundação de Amparo à Pesquisa do Estado do Rio de Janeiro (FAPERJ), Conselho Nacional de Desenvolvimento Científico e Tecnológico (CNPq) and Universidade do Estado do Rio de Janeiro (UERJ).

\section{REFERENCES}

Agra MF, França PF, Barbosa-Filho JM 2007. Synopsis of the plants known as medicinal and poisonous in Northeast of Brazil. Rev Bras Farmacogn 17: 114-140.
Ahmed ZF, Shoaib AM, Wassel GM, Sayyad SM 1972. Phytochemical study of Lantana camara L. Planta Med 21: 282-288.

Alberts B, Bray D, Lewis J, Raff M, Roberts K, Watson JD 2002. Molecular Biology of The Cell. New York \& London: Garland Publishing Inc.

Ammus S, Yunis A 1989. Drug-induced red cell dyscrasias. Blood Rev 3: 71-82.

Barbosa-Filho JM, Medeiros KCP, Diniz MFFM, Batista LM, Athayde-Filho PF, Silva MS, Cunha EVL, Almeida JRGS, Quintans-Júnior LJ 2006. Natural products inhibitors of the enzyme acetylcholinesterase. Rev Bras Farmacogn 16: 258-285.

Brandão MGL, Cosenza GP, Moreira RA, Monte-Mor RLM 2006. Medicinal plants and other botanical products from the Brazilian Official Pharmacopoeia. Rev Bras Farmacogn 16: 408-420.

Cavalcanti TC, Gregorini CG, Guimarães F, Rettori O, Vieira-Matos AN 2003. Changes in red blood cell osmotic fragility induced by total plasma and plasma fractions obtained from rats bearing progressive and regressive variants of the Walker 256 tumor. Braz J Med Biol Res 36: 887-895.

Cruz Silva MM, Madeira VMC, Almeida LM, Custódio JBA 2000. Hemolysis of human erythrocytes induced by tamoxifen is related to disruption of membrane structure. Biochim Biophys Acta 1464: 49-61.

Dacie J, Lewis SM 2001. Practical Haematology. London: Churchill Livingstone.

Didelon J, Mazeron P, Muller S, Stoltz JF 2000. Osmotic fragility of the erythrocyte membrane: Characterization by modeling of the transmittance curve as a function of the $\mathrm{NaCl}$ concentration. Biorheol 37: 409-416.

Ghisalberti EL 2000. Lantana camara Linn. Fitoterapia 71 : 467-485.

Giani TS, Paoli S, Presta GA, Maiworm AI, Santos-Filho SD, Fonseca AS, Bernardo-Filho M 2007. Assessment of effects of a formula used in the traditional Chinese medicine (Buzhong Yi Qi Wan) on the morphologic and osmotic fragility of red blood cells. Rev Bras Farmacogn 17: 501-507.

Herbert JM, Maffrand JP, Taoubi K, Augereau JM, Fouraste I, Gleye J 1991. Verbascoside isolated from Lantana camara, an inhibitor of protein kinase C. J Nat Prod 54: 1595-1600.

Hernandes T, Canales M, Avila JG, Duran A, Caballero J, Romo de Vivar A, Lira R 2003. Ethnobotany and antibacterial activity of some plants used in tradional medicine of Zapotitlann de las Salinas. $J$ Ethnopharmacol 88: 181-188.

Hubner Y, Hoettges KF, Kass GE, Ogin SL, Hughes MP 2005. Parallel measurements of drug actions on erythrocytes by dielectrophoresis, using a three-dimensional electrode design. IEE Proc Nanobiotechnol 152: 150-154.

Junqueira LC, Carneiro J 2004. Histologia Básica. Rio de 
Janeiro: Guanabara Koogan.

Khanna R, Chang SH, Andrabi S, Azam M, Kim A, Rivera A, Brugnara C, Low PS, Liu SC, Chishti AH 2002. Headpiece domain of dematin is requires for the stability of the erythrocyte membrane. Proc Natl Acad Sci U.S.A.: 6637-6642.

Li A, Seipelt H, Muller C, Shi Y, Artmann M 1999. Effects of salicylic acid derivatives on red blood cell membranes. Pharmacol Toxicol 85: 206-211.

Misra N, Sharma M, Raj K, Dangi A, Srivastava S, MisraBhattacharya S 2007. Chemical constituents and antifilarial activity of Lantana camara against human lymphatic filariid Brugia malayi and rodent filariid Acanthocheilonema viteae maintained in rodent hosts. Parasitol Res 100: 439-448.

Nwafor A, Coakley WT 1986. Charge-independent effects of drugs on erythrocyte morphology. Biochem Pharmacol 35: 953-957.

Oliveira JF, Avila AS, Braga ACS, Oliveira MBN, Boasquevisque EM, Jales RL, Cardoso VN, BernardoFilho M 2002. Effect of extract of medicinal plants on the labeling of blood elements with technetium-99m and on the morphology of red blood cells: I - a study with Paullinia cupana. Fitoterapia 73: 305-312.

Oliveira JF, Santos-Filho SD, Catanho MTJA, Srivastava SC, Lima-Filho GL, Bernardo-Filho M 2003. Effect of extract of medicinal plants on the labeling of blood elements with technetium-99m and on the morphology of red blood cells (RBC): Toxicological actions of roast coffee beans (Coffea arabica). Indian J Nucl Med 18: 52-56.

Oliveira JF, Brito LC, Frydman JNG, Santos-Filho SD, Bernardo-Filho M 2005 An aqueous extract of Pfaffia sp. does not alter the labeling of blood constituents with technetium- $99 \mathrm{~m}$ and the morphology of the red blood cells. Rev Bras Farmacogn 15: 126-132.

Pompei LM, Carvalho FM, Ortiz SC, Motta MC, Cruz RJ, Melo NR 2005. Morphometric evaluation of effects of two sex steroids on mammary gland of female rats. Maturitas 5: 370-379.

Presta GA, Fonseca AS, Bernardo-Filho M 2007. A Chrysobalanus icaco extract alters the plasmid topology and the effects of stannous chloride on the DNA of plasmids. Rev Bras Farmacogn 17: 331-335.

Sagar L, Sehgal R, Ojha S 2005. Evaluation of antimotility effect of Lantana camara L. var. acuelata constituents on neostigmine induced gastrointestinal transit in mice. BMC Complement Altern Med 5: 18-23.

Santos NC, Martins-Silva J, Saldanha C 2005. Gramicidin $\mathrm{D}$ and dithiothreitol effects on erythrocyte exovesiculation. Cell Biochem Biophys 43: 419-430.

Scheiman JM, Elta GH 1990. Gastroduodenal mucosal damage with salsalate versus aspirin: results of experimental models and endoscopic studies in humans. Semin Arthritis Rheum 20: 121-127.
Shacter E, Weitzman SA 2002. Chronic inflammation and cancer. Oncology 16: 217-226.

Shashi BM, Niranjan PS, Subodh KR, Sharma OP 1994. Potential antitumor agents from Lantana camara: Structures of flavonoid and phenylpropanoid glycosides. Tetrahedron 50: 9439-9446.

Suwalsky M, Hernandez PL, Villena F, Sotomayor CP 2003. The anticancer drug cytarabine does not interact with the human erythrocyte membrane. Z Naturforsch 58c: 885-890.

Uzcategui B, Avila D, Heberto SR, Quintero L, Ortega J, Gonzalez YB 2004. Anti-inflammatory, antinociceptive and antipyretic effects of Lantana trifolia Linnaeus in experimental animals. Invest Clin 45: 317-322.

Zhang $\mathrm{X}$, Inukai $\mathrm{T}$, Hirose $\mathrm{K}$, Akahane $\mathrm{K}$, Nemoto A, Takahashi K, Sato H, Kagami K, Goi K, Sugita K, Nakazawa S 2005. Induction of impaired membrane phospholipid asymmetry in mature erythrocytes after chemotherapy. Int J Hematol 82: 132-136.

Zheng HQ, Wei N, Wang LF, He P 2006. Effects of Lantana camara Leaf Extract on the activity of superoxide dismutase and accumulation of $\mathrm{H}_{2} \mathrm{O}_{2}$ in water hyacinth leaf. Zhi Wu Sheng Li Yu Fen Zi Sheng Wu Хие Хие Bao 32: 189-194. 